\title{
Bước đầu nghiên cứu tạo enzyme pectinase dạng bột từ Aspergillus niger và khảo sát một số đặc tính của chế phẩm
}

\section{An initial study of powdered pectinase from Aspergillus niger and investigation of biochemical characterization of preparation}

\author{
Đỗ Thị Hiền ${ }^{1 *}$, Huỳnh Phan Phương Trang ${ }^{1}$ \\ ${ }^{1}$ Trường Đại học Công nghiệp Thực phẩm Thành phố Hồ Chí Minh, Việt Nam \\ *Tác giả liên hệ, Email: hiendt@cntp.edu.vn
}

\section{THÔNG TIN}

DOI: $10.46223 / \mathrm{HCMCOUJS.}$

tech.vi.14.1.445.2019

Ngày nhận: 14/11/2018

Ngày nhận lại: 21/12/2018

Duyệt đăng: 21/12/2018

Tù khóa:

Aspergillus niger, đặc tính sinh hóa pectinase, pectinase, sấy phun

Keywords:

Aspergillus niger, biochemical characterization pectinase, pectinase, spray drying

\section{TÓM TẮT}

Enzyme pectinase dạng bột dễ vận chuyển và bảo quản. Vì vậy, nghiên cứu đã sử dụng enzyme pectinase hoạt tính 194UI/mL từ Aspergillus niger để tạo chế phẩm dạng bột bằng phương pháp sấy phun (nồng độ chất trợ sấy maltodextrin $10 \%$ (w/v), nhiệt độ sấy $130^{\circ} \mathrm{C}$, tốc độ nhập liệu $\left.288 \mathrm{~mL} / \mathrm{h}\right)$. Bên cạnh đó, nghiên cứu đã xác định được thông số động học của chế phẩm enzyme $\mathrm{Km}$ là $28,4 \mathrm{mg} / \mathrm{mL}$, pH tối ưu 5,0 , nhiệt độ tối ưu $40^{\circ} \mathrm{C}$, $\mathrm{Cu}^{2+}$ là chất hoạt hóa và $\mathrm{Ag}^{+}$là chất kìm hãm hoạt động enzyme.

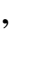

ABSTRACT
Powdered pectinase is easy to transport and store.
Therefore, the study used pectinase enzyme $194 \mathrm{UI} / \mathrm{mL}$ from
Aspergillus niger to produce powdered enzyme preparation by
spray drying $(10 \%$ maltodextrin (w/v), drying temperature
$130^{\circ} \mathrm{C}$, input speed $\left.288 \mathrm{~mL} / \mathrm{h}\right)$. In addition, the study determined
the kinetic parameters of the enzyme preparation at $\mathrm{Km}$
$28,4 \mathrm{mg} / \mathrm{mL}$ with $\mathrm{pH}$ and temperature optimum of 5,0 and $40^{\circ} \mathrm{C}$,
$\mathrm{Cu}^{2+}$ was found to activate and $\mathrm{Ag}^{+}$was the inhibitor of enzyme
activity.

\section{1. Đặt vấn đề}

Enzyme pectinase được thu nhận chủ yếu nhờ vi nấm, trong đó Aspergillus niger được cho là có khả năng sinh nhiều enzyme pectinase khi nuôi cấy trong môi trường thích hợp. Pectinase từ Aspergillus niger là enzyme ngoại bào nên việc thu nhận sản phẩm khá thuận lợi và chế phẩm enzyme từ vi sinh vật này được FDA công nhận là an toàn khi ứng dụng trong công nghệ thực phẩm.

Sử dụng enzyme thu nhận từ Aspergillus spp. có khả năng cải thiện hiệu suất thu hồi, làm trong và làm giảm độ nhớt của dịch đu đủ (Nakkeeran, Umesh-Kumar, \& Subramanian, 
2011). Bên cạnh đó, Kant, Vohra, và Gupta (2013) đã sử dụng enzyme này để làm trong dịch ép ổi. Polygalactorunase thu nhận từ Aspergillus niger nuôi cấy trên nguồn cơ chất vỏ chuối có tác dụng làm trong dịch ép chuối (Barman, Sit, Badwaik, \& Deka, 2015). Sử dụng Polygalactorunase từ Neosartorya fisheri làm trong dịch ép táo và dâu (Pan et al., 2015). Ngoài ra pectinase được xem như là một trong những chế phẩm enzyme quan trọng trong sản xuất rượu vang và nước trái cây lên men có độ cồn thấp (P. N. M. Nguyen, Che, Ly, \& Chau, 2011). Trong sản xuất cà phê và ca cao, người ta dùng chế phẩm pectinase để hỗ trợ quá trình tách lớp keo ở trên bề mặt của hạt (Tran, Duong, \& Le, 2012). Trong ngành công nghiệp giấy pectinase làm tăng hiệu quả khử lignin và làm sang màu bột giấy (Ahlawat, Mandhan, Dhiman, Kumar, \& Sharma, 2008).

Sấy phun là công nghệ tạo sản phẩm dạng bột, thời gian sấy ngắn, dễ sản xuất ở quy mô công nghiệp. Sấy phun là hình thức bao gói có sử dụng chất trợ sấy (Desai \& Park, 2005). Chất trợ sấy là yếu tố làm giảm ảnh hưởng của nhiệt độ đối với các protein trong quá trình sấy. Đồng thời, chất trợ sấy bảo vệ enzyme tránh khỏi tác động của nhiệt độ, $\mathrm{pH}$ khi sử dụng trong các điều kiện khác nhau (Cabral, Said, \& Oliveira, 2009). Maltodextrin là chất trợ sấy được sử dụng phổ biến hiện nay và không làm ảnh hưởng đến tác nhân cần sấy, giá thành rẻ.

Nghiên cứu mong muốn sử dụng chế phẩm enzyme pectinase từ Aspergillus niger được nuôi cấy trên môi trường có bổ sung vỏ cam - nguồn nguyên liệu giàu pectin, một phụ phẩm thường bị bỏ đi hoặc làm phân bón hữu cơ sau khi ép lấy nước. Để thuận tiện trong quá trình sử dụng và bảo quản, tiến hành tạo chế phẩm enzyme pectinase dạng bột bằng phương pháp sấy phun. Bên cạnh đó, để có hướng sử dụng chế phẩm enzyme dạng bột, nhóm nghiên cứu đã tiến hành xác định một số yếu tố: thông số động học, nhiệt độ, $\mathrm{pH}$, các chất hoạt hóa và ức chế có ảnh hưởng đến hoạt động enzyme.

\section{2. Đối tượng, vật liệu và phương pháp nghiên cứu}

\section{1. Đối tựng và vật liệu nghiên cứu}

Chế phẩm enzyme pectinase thu nhận từ Aspergillus niger (Huynh \& Do, 2018).

Maltodextrin DE 10 của Himedia (Ấn Độ).

\subsection{Phương pháp}

\subsubsection{Chuẩn bị chế phẩm enzyme (Huynh \& Do, 2018)}

Nuôi cấy Aspergillus niger trong môi trường lỏng với vỏ cam $80 \mathrm{~g} / \mathrm{L}$ (hàm lượng pectin $0,72 \mathrm{~g} / \mathrm{L}$ ) - sử dụng vỏ cam trắng (phế phẩm nhà máy sản xuất nước ép cam), tỷ lệ vỏ cam:glucose là $4: 2$, nguồn nitrogen thích hợp là peptone $4 \%(\mathrm{w} / \mathrm{v})$, tỷ lệ giống $2 \%(\mathrm{v} / \mathrm{v})$ với mật độ giống $10^{7}$ bào tử $/ \mathrm{mL}, \mathrm{pH} 5,0$ và thời gian nuôi cấy 72 giờ.

Dịch nuôi cấy được ly tâm với tốc độ 4500 vòng/phút trong 15 phút, thu dịch enzyme và xác định hoạt tính theo Mohsen, Bazaraa, và Doukani (2009) là 194UI/mL. 


\subsubsection{Các phuoơng pháp phân tích}

- Xác định độ ẩm bằng cân sấy ẩm Ohaus MB 45.

- Phương pháp xác định hoạt tính enzyme pectinase (Mohsen et al., 2009).

Cho enzyme tác dụng với cơ chất pectin, sản phẩm tạo thành là acid galacturonic tạo màu với thuốc thử DNS (Dinitrosalicylic acid), đo mật độ quang ở bước sóng $575 \mathrm{~nm}$.

Hoạt tính enzyme pectinase đo bởi lượng đường khử được cắt ra từ pectin bằng phương pháp Dinitrosalicylic acid. Một đơn vị hoạt tính enzyme pectinase được đo bởi $1 \mu \mathrm{mol}$ galacturonic acid giải phóng trong 1 phút trên $1 \mathrm{~mL}$. Sử dụng đường chuẩn D-galacturonic acid.

- Xác định hàm lượng protein bằng phương pháp Bradford dựa trên phản ứng của thuốc nhuộm Coomassie Blue G250 với protein (Walker, 1996).

\subsubsection{Khảo sát ảnh hưởng của nồng độ chất trộ sấy}

Chuẩn bị $50 \mathrm{~mL}$ dịch enzyme pectinase, bổ sung maltodextrin với nồng độ $10,15,20$, $25,30 \%$ vào, khuấy tan hoàn toàn maltodextrin. Các mẫu trên sẽ được sấy phun ở $140^{\circ} \mathrm{C}$, tốc độ nhập liệu là $252 \mathrm{~mL} / \mathrm{h}$. Xác định độ ẩm (\%), hoạt tính enzyme (UI/g) và hàm lượng protein $(\mathrm{mg} / \mathrm{g})$.

\subsubsection{Khảo sát ảnh hwởng của nhiệt độ sấy}

Chuẩn bị $50 \mathrm{~mL}$ dịch enzyme pectinase, bổ sung maltodextrin với nồng độ thích hợp thí nghiệm 2.3. Sấy phun enzyme ở nhiệt độ sấy từ $120^{\circ} \mathrm{C}$ đến $170^{\circ} \mathrm{C}$ (bước nhảy $10^{\circ} \mathrm{C}$ ), tốc độ nhập liệu là $252 \mathrm{~mL} / \mathrm{h}$. Xác định độ ẩm $(\%)$, hoạt tính enzyme (UI/g) và hàm lượng protein $(\mathrm{mg} / \mathrm{g})$.

\subsubsection{Khảo sát ảnh hưởng của tốc độ bơm nhập liệu}

Chuẩn bị $50 \mathrm{~mL}$ dịch enzyme pectinase, bổ sung maltodextrin với nồng độ thích hợp thí nghiệm 2.3, sấy phun enzyme pectinase với nhiệt độ thích hợp thí nghiệm 2.4, tốc độ nhập liệu từ $180-360 \mathrm{~mL} / \mathrm{h}$ (bước nhảy $36 \mathrm{~mL} / \mathrm{h})$. Xác định độ ẩm $(\%)$, hoạt tính enzyme $(\mathrm{UI} / \mathrm{g})$ và hàm lượng protein $(\mathrm{mg} / \mathrm{g})$.

\subsubsection{Xác định thông số động học của enzyme}

Tiến hành theo Bảng sau:

\section{Bảng 1}

Xác định thông số động học của enzyme

\begin{tabular}{|l|c|c|c|c|c|c|c|}
\hline \multirow{2}{*}{ Hóa chất } & \multirow{2}{*}{ Đơn vị } & \multicolumn{6}{|c|}{ Các ống nghiềm } \\
\cline { 3 - 9 } & & $\mathbf{0}$ & $\mathbf{1}$ & $\mathbf{2}$ & $\mathbf{3}$ & $\mathbf{4}$ & $\mathbf{5}$ \\
\hline Pectin $1 \%$ & $\mathrm{ml}$ & 0 & 1 & 2 & 3 & 4 & 5 \\
\hline Đệm $\mathrm{pH}=5$ & $\mathrm{ml}$ & 5 & 4 & 3 & 2 & 1 & 0 \\
\hline Pectinase $2 \%$ & $\mathrm{ml}$ & 5 & 5 & 5 & 5 & 5 & 5 \\
\hline \multicolumn{7}{|l|}{} \\
\hline
\end{tabular}




\begin{tabular}{|c|c|c|c|c|c|c|c|}
\hline \multirow{2}{*}{ Hóa chất } & \multirow{2}{*}{ Đơn vị } & \multicolumn{6}{|c|}{ Các ống nghiệm } \\
\hline & & $\mathbf{0}$ & 1 & 2 & 3 & 4 & 5 \\
\hline \multicolumn{8}{|c|}{ Đun cách thủy 3 phút, làm nguội, lọc lây dịch bên dưới } \\
\hline \multirow{2}{*}{ Hóa chất } & \multirow{2}{*}{ Đơn vị } & \multicolumn{6}{|c|}{ Các ống nghiệm } \\
\hline & & 0 ' & 1 ' & 2 & 3 ' & $4{ }^{\prime}$ & 5 ' \\
\hline Dịch lọc & $\mathrm{ml}$ & 1 & 1 & 1 & 1 & 1 & 1 \\
\hline Thuốc thử DNS & $\mathrm{ml}$ & 3 & 3 & 3 & 3 & 3 & 3 \\
\hline \multicolumn{8}{|c|}{ Bịt ống nghiệm bằng giấy nhôm, đun cách thủy 15 phút } \\
\hline \multicolumn{8}{|c|}{ Làm lạnh đến nhiệt độ phòng } \\
\hline \multicolumn{8}{|c|}{ Đo OD tại $\lambda=575 \mathrm{~nm}$} \\
\hline
\end{tabular}

Nguồn: Kết quả phân tích dữ liệu của nhóm nghiên cứu

Lượng sản phẩm tạo thành được xác định dựa vào đường chuẩn $\mathrm{D}$ galacturonic theo phương pháp (Miller, 1959). Qua đó xây dựng đồ thị của phương trình Lineweaver - Burk, từ đó xác định được thông số động học $\mathrm{Km}$ và Vmax của enzyme pectinase.

\subsubsection{Khảo sát ảnh hưởng của $p H$}

Sử dụng $1 \mathrm{~mL}$ pectin $1 \%$ và $0,5 \mathrm{~mL}$ dung dịch enzyme trong các bộ đệm khác nhau nồng độ $100 \mathrm{mM}$ ở khoảng $\mathrm{pH} 1,0-10,0$, ủ $37^{\circ} \mathrm{C}$ trong 30 phút. Thêm $3 \mathrm{ml} \mathrm{DNS}$, bịt ống nghiệm bằng giấy nhôm, đun cách thủy 15 phút, để nguội ở nhiệt độ phòng, đo $\mathrm{OD}$ tại $\lambda=575 \mathrm{~nm}$.

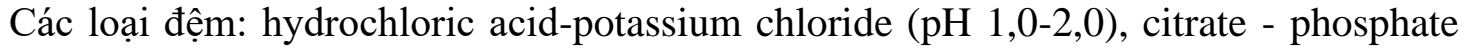

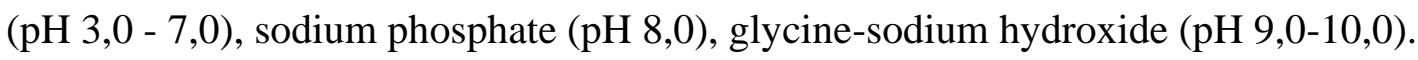

Xác định hoạt tính enzyme (UI/g).

\subsubsection{Khảo sát ảnh hưởng của nhiệt độ}

Sử dụng $1 \mathrm{~mL}$ pectin $1 \%$ và $0,5 \mathrm{~mL}$ dung dịch enzyme có $\mathrm{pH}$ thích hợp từ thí nghiệm 2.7 ở nhiệt độ $25^{\circ} \mathrm{C}, 30^{\circ} \mathrm{C}, 37^{\circ} \mathrm{C}, 40^{\circ} \mathrm{C}, 45^{\circ} \mathrm{C}, 50^{\circ} \mathrm{C}, 55^{\circ} \mathrm{C}$, ủ trong 30 phút, 60 phút, 90 phút. Thêm $3 \mathrm{ml}$ DNS, bịt ống nghiệm bằng giấy nhôm, đun cách thủy 15 phút, để nguội ở nhiệt độ phòng, đo $\mathrm{OD}$ tại $\lambda=575 \mathrm{~nm}$.

Xác định hoạt tính enzyme (UI/g).

\subsubsection{Xác định ảnh hưởng của chất ức chế và chất hoạt hóa}

Sử dụng $1 \mathrm{~mL}$ pectin $1 \%$ và $0,5 \mathrm{~mL}$ dung dịch enzyme ở $\mathrm{pH}$ thích hợp từ thí nghiệm 2.7 , nhiệt độ và thời gian thích hợp từ thí nghiệm 2.8. Bổ sung $0,1 \mathrm{~mL}$ các ion kim loại $1 \mathrm{mM}: \mathrm{Ca}^{2+}$, $\mathrm{Mn}^{2+}, \mathrm{Co}^{2+}, \mathrm{Cu}^{2+}, \mathrm{Zn}^{2+}, \mathrm{K}^{2+}, \mathrm{Na}^{2+}, \mathrm{Ag}^{2+}$ và các chất ức chế protein như KMnO4, EDTA. Thêm $3 \mathrm{ml}$ DNS, bịt ống nghiệm bằng giấy nhôm, đun cách thủy 15 phút, để nguội ở nhiệt độ phòng, đo OD tại $\lambda=575 \mathrm{~nm}$.

Xác định hoạt tính enzyme (UI/g), hoạt tính tương đối (\%). 


\subsubsection{Xủ lý số liệu}

Các thí nghiệm được lặp lại 3 lần, kết quả được ghi nhận và xử lý thống kê bằng phần mềm Statgraphic Centurion XV.I, Excell 2013 với mức độ tin cậy 95\%.

\section{Kết quả và thảo luận}

\subsection{Khảo sát ảnh hưởng của nồng độ chất trọ̉ sấy}

Nồng độ chất trợ sấy có ảnh hưởng đến hoạt tính, hàm lượng protein và độ ẩm của chế phẩm enzyme sau sấy phun (Bảng 2).

\section{Bảng 2}

Ảnh hưởng của nồng độ chất trợ sấy

\begin{tabular}{cccc}
\hline $\begin{array}{c}\text { Nồng độ } \\
(\mathbf{w} / \mathbf{v})\end{array}$ & $\begin{array}{c}\text { Độ ẩm } \\
(\mathbf{\%})\end{array}$ & $\begin{array}{c}\text { Hoạt tính } \\
(\mathbf{U} \mathbf{I} / \mathbf{g})\end{array}$ & $\begin{array}{c}\text { Hàm lượng } \\
\text { protein }(\mathbf{m g} / \mathbf{g})\end{array}$ \\
\hline 10 & $5,733 \pm 0,015^{\mathrm{d}}$ & $2455,04 \pm 10,99^{\mathrm{d}}$ & $17,93 \pm 0,50^{\mathrm{d}}$ \\
15 & $5,230 \pm 0,265^{\mathrm{c}}$ & $2343,49 \pm 10,99^{\mathrm{c}}$ & $16,19 \pm 0,67^{\mathrm{c}}$ \\
20 & $4,950 \pm 0,040^{\mathrm{b}}$ & $2324,29 \pm 35,50^{\mathrm{c}}$ & $13,87 \pm 0,43^{\mathrm{b}}$ \\
25 & $4,973 \pm 0,015^{\mathrm{b}}$ & $1692,19 \pm 13,62^{\mathrm{b}}$ & $12,71 \pm 0,67^{\mathrm{b}}$ \\
30 & $3,873 \pm 0,021^{\mathrm{a}}$ & $1042,08 \pm 15,69^{\mathrm{a}}$ & $10,97 \pm 1,09^{\mathrm{a}}$ \\
\hline
\end{tabular}

(a,b,c, d là các chữ cái thể hiện khác biệt có ý nghĩa thống kê ở độ tin cậy $95 \%$, các nghiệm thức có phân hạng giống nhau thì chưa thể hiện rõ sự khác biệt về ý nghĩa thống kê)

Nguồn: Kết quả phân tích dữ liệu của nhóm nghiên cứu

Hoạt tính enzyme giảm dần từ 2455,04 đến 1042,08UI/g khi nồng độ maltodextrin tăng dần (10-30\%). Nguyên nhân có thể do maltodextrin cản trở quá trình phân giải cơ chất của enzyme. Bên cạnh đó, hàm lượng protein giảm dần khi nồng độ maltodextrin tăng dần, từ 17,93 còn $10,97 \mathrm{mg} / \mathrm{g}$.

Theo nghiên cứu của Dao, Nguyen, Do, và Nguyen (2017) đã khảo sát nồng độ chất trợ sấy sữa gầy $10 \%(\mathrm{w} / \mathrm{v})$ là thích hợp nhất cho quá trình sấy phun bromelain. Như vậy ở nồng độ chất trợ sấy $10 \%$ thì hoạt tính enzyme cao nhất $(2455,1 \mathrm{UI} / \mathrm{g})$ và độ ẩm của chế phẩm $5,7 \%$ đáp ứng yêu cầu bảo quản enzyme.

\subsection{Khảo sát ảnh hưởng của nhiệt độ sấy}

Theo nghiên cứu của (Heller, Carpenter, \& Randolph, 1999; Samborska, WitrowaRajchert, \& Gonçalves, 2005) cho thấy hoạt tính enzyme phụ thuộc chủ yếu vào nhiệt độ không khí đầu vào và sự phân bố nhiệt độ trong thiết bị sấy. Kết quả nghiên cứu cho thấy hoạt tính enzyme giảm dần khi tăng nhiệt độ sấy từ $130-170^{\circ} \mathrm{C}$ (Bảng 3 ).

\section{Bảng 3}

Ảnh hưởng của nhiệt độ sấy

\begin{tabular}{cccc}
\hline $\begin{array}{c}\text { Nhiệt độ } \\
\left({ }^{\circ} \mathbf{C}\right)\end{array}$ & $\begin{array}{c}\text { Độ ẩm } \\
(\%)\end{array}$ & $\begin{array}{c}\text { Hoạt tính } \\
(\mathbf{U} / \mathbf{g})\end{array}$ & $\begin{array}{c}\text { Hàm lượng } \\
\text { protein }(\mathbf{m g} / \mathbf{g})\end{array}$ \\
\hline 130 & $6,217 \pm 0,025^{\mathrm{e}}$ & $2489,82 \pm 52,43^{\mathrm{e}}$ & $19,09 \pm 0,44^{\mathrm{d}}$ \\
\hline
\end{tabular}




\begin{tabular}{cccc}
\hline $\begin{array}{c}\text { Nhiệt độ } \\
(\stackrel{\mathbf{C}}{ })\end{array}$ & $\begin{array}{c}\text { Độ ẩm } \\
(\boldsymbol{\%})\end{array}$ & $\begin{array}{c}\text { Hoạt tính } \\
(\mathbf{U} / \mathbf{g})\end{array}$ & $\begin{array}{c}\text { Hàm lượng } \\
\text { protein }(\mathbf{m g} / \mathbf{g})\end{array}$ \\
\hline 140 & $5,723 \pm 0,021^{\mathrm{d}}$ & $2391,46 \pm 10,80^{\mathrm{d}}$ & $18,07 \pm 0,25^{\mathrm{d}}$ \\
150 & $5,593 \pm 0,015^{\mathrm{c}}$ & $2243,93 \pm 3,60^{\mathrm{c}}$ & $15,03 \pm 0,67^{\mathrm{c}}$ \\
160 & $4,953 \pm 0,021^{\mathrm{b}}$ & $1698,18 \pm 67,74^{\mathrm{b}}$ & $11,99 \pm 0,67^{\mathrm{b}}$ \\
170 & $3,757 \pm 0,021^{\mathrm{a}}$ & $1303,56 \pm 14,98^{\mathrm{a}}$ & $9,81 \pm 0,90^{\mathrm{a}}$ \\
\hline
\end{tabular}

(a, b, c, d là các chữ cái thể hiện khác biệt có ý nghĩa thống kê ở độ tin cậy $95 \%$, các nghiệm thức có phân hạng giống nhau thì chưa thể hiện rõ sự khác biệt về ý nghĩa thống kê)

Nguồn: Kết quả phân tích dữ liệu của nhóm nghiên cứu

Khi tăng nhiệt độ sấy, enzyme tiếp xúc với nhiệt độ cao sẽ bị biến tính nên hoạt tính enzyme giảm dần (từ 2489,8 còn 1303,6UI/g). Kết quả này cũng tương đồng với nghiên cứu của Devakate, Patil, Waje, và Thorat (2009). Độ ẩm của chế phẩm cũng giảm (từ 6,2 còn $3,8 \%$ ) khi tăng nhiệt độ sấy từ $130-170^{\circ} \mathrm{C}$. Theo nghiên cứu của Samborska và cộng sự (2005), nhiệt độ không khí sấy sẽ ảnh hưởng đến quá trình bốc hơi nước ra khỏi dung dịch sấy, khi tốc độ nhập liệu không thay đổi nhiệt độ sấy càng tăng thì nước bốc hơi khỏi dung dịch càng tăng do vậy độ ẩm chế phẩm enzyme càng giảm. Ngoài ra ở nhiệt độ sấy $120^{\circ} \mathrm{C}$ chế phẩm enzyme thu được có độ ẩm cao, chế phẩm tạo ra dạng bột ướt dính lại thành buồng sấy, khó thu hồi và bảo quản chế phẩm. Hoạt tính enzyme cao nhất nhiệt độ $130^{\circ} \mathrm{C}$ là $2489,8 \mathrm{UI} / \mathrm{g}$. Vì vậy, nhiệt độ sấy $130^{\circ} \mathrm{C}$ sẽ được chọn để thực hiện các thí nghiệm tiếp theo.

\subsection{Khảo sát ảnh hương của tốc độ bơm nhập liệu}

\section{Bảng 4}

Ảnh hưởng của tốc độ bơm nhập liệu

\begin{tabular}{cccc}
\hline $\begin{array}{c}\text { Tốc độ bơm nhập liệu } \\
(\mathbf{m L} / \mathbf{h})\end{array}$ & $\begin{array}{c}\text { Độ ẩm } \\
(\boldsymbol{\%})\end{array}$ & $\begin{array}{c}\text { Hoạt tính } \\
(\mathbf{U I} / \mathbf{g})\end{array}$ & $\begin{array}{c}\text { Hàm lượng protein } \\
(\mathbf{m g} / \mathbf{g})\end{array}$ \\
\hline 180 & $4,913 \pm 0,015^{\mathrm{a}}$ & $2223,54 \pm 23,96^{\mathrm{a}}$ & $10,25 \pm 0,50^{\mathrm{a}}$ \\
216 & $5,427 \pm 0,021^{\mathrm{b}}$ & $2326,69 \pm 12,97^{\mathrm{b}}$ & $12,71 \pm 0,66^{\mathrm{b}}$ \\
252 & $5,702 \pm 0,021^{\mathrm{c}}$ & $2552,19 \pm 5,50^{\mathrm{c}}$ & $17,64 \pm 0,25^{\mathrm{c}}$ \\
288 & $6,067 \pm 0,083^{\mathrm{d}}$ & $2655,34 \pm 12,64^{\mathrm{d}}$ & $18,94 \pm 0,25^{\mathrm{d}}$ \\
\hline
\end{tabular}

(a,b,c, d là các chữ cái thể hiện khác biệt có ý nghĩa thống kê ở độ tin cậy $95 \%$, các nghiệm thức có phân hạng giống nhau thì chưa thể hiện rõ sự khác biệt về ý nghĩa thống kê)

Nguồn: Kết quả phân tích dữ liệu của nhóm nghiên cứu

Hoạt tính enzyme tăng dần $(2223,5$ đến $2655,3 \mathrm{UI} / \mathrm{g})$ và hàm lượng protein tăng dần (10,3 đến $18,9 \mathrm{~g} / \mathrm{mg}$ ) khi tăng tốc độ nhập liệu từ $180-288 \mathrm{~mL} / \mathrm{h}$. Ở tốc độ bơm nhập liệu thấp, kích thước hạt tạo ra nhỏ hơn, bề mặt tiếp xúc của hạt với nhiệt độ tăng, thời gian tiếp xúc dài hơn làm enzyme dễ bị biến tính (Samborska et al., 2005). Độ ẩm của chế phẩm enzyme cũng tăng dần $(4,9$ đến $6,1 \%)$ khi tăng tốc độ bơm nhập liệu từ $180-288 \mathrm{~mL} / \mathrm{h}$. Ở các tốc độ nhập liệu 324 và $360 \mathrm{~mL} / \mathrm{h}$, enzyme thu được có độ ẩm cao, bị dính lên thành buồng sấy, chế phẩm enzyme tạo ra ở dạng bột ướt gây khó khăn trong việc thu hồi, bảo quản và sử dụng. Kết quả này cũng tương đồng với nghiên cứu của N. T. T. Nguyen và Nguyen (2011), Devakate và cộng sự 
(2009), Dao và cộng sự (2017), tốc độ bơm nhập liệu có ảnh hưởng lớn đến lưu lượng dòng nhập liệu, năng suất thiết bị và cả nhiệt độ không khí đầu ra. Tốc độ bơm nhập liệu tăng đồng nghĩa với thời gian lưu của vật liệu sấy trong buồng sấy giảm, lượng hơi nước thoát ra ít hơn làm độ ẩm tăng.

\subsection{Xác định thông số động học của enzyme}

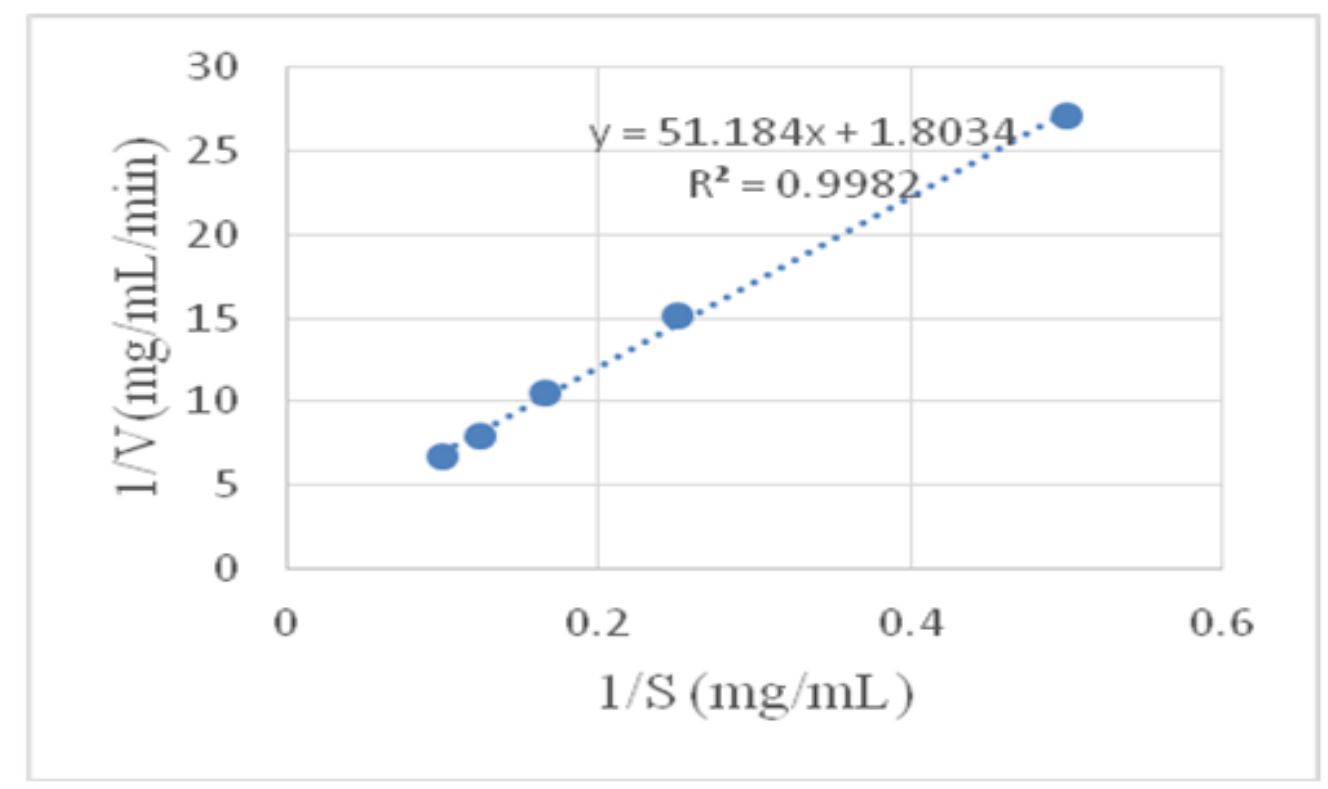

Hình 1. Đồ thị Lineweaver-Burk

Hằng số Michaelis Menten $(\mathrm{Km})$ đặc trưng cho ái lực enzyme và cơ chất. Khi Km càng nhỏ thì ái lực của enzyme và cơ chất càng lớn (vận tốc phản ứng do enzyme xúc tác càng lớn). Dựa vào mối tương quan giữa vận tốc phản ứng của enzyme và nồng độ cơ chất xây dựng phương trình Lineweaver-Burk có dạng $\mathrm{y}=51,184 \mathrm{x}+1,8034$, từ đó tính được $\mathrm{Km}=28,4$ $(\mathrm{mg} / \mathrm{ml})$ và $\operatorname{Vmax}=0,56(\mathrm{mg} / \mathrm{ml} / \mathrm{phút})$. Enzyme pectinase đã tinh sạch từ A.niger có $\mathrm{Km}=$ 2,3mg/ml (Anand, Yadav, \& Yadav, 2017), $\mathrm{Km}=2,4 \mathrm{mg} / \mathrm{ml}$ (Parenicova, Benen, Kester, \& Visser, 1998).

Ngoài ra một số nghiên cứu về pectinase thu nhận từ các chủng vi sinh vật khác nhau thì giá trị Km trong khoảng 0,1-0,5 (Chen et al., 2014; Martins, Leite, Silva, \& Gomes, 2013). Như vậy, có thể do chế phẩm enzyme tạo ra chưa được tinh sạch nên hằng số $\mathrm{Km}$ cao hơn khoảng 10 lần so với enzyme đã tinh sạch từ các nghiên cứu trên.

\subsection{Khảo sát ảnh huởng của pH}

Hoạt tính enzyme tăng dần khi pH tăng từ 1 đến 5 đạt giá trị lớn nhất ở pH $5(2650 \mathrm{UI} / \mathrm{g})$. Sau đó hoạt tính enzyme giảm mạnh khi pH tăng từ 6 đến 10 , đặc biệt ở $\mathrm{pH}$ từ 8 đến 10 thì enzyme gần như mất hoạt tính. Theo Anand và cộng sự (2017) đã nghiên cứu sản xuất, tinh chế và xác định đặc tính hóa sinh của một exo-polygalacturonase từ Aspergillus niger MTCC 478. Nhóm tác giả đã khảo sát hoạt tính enzyme trong khoảng $\mathrm{pH}$ từ 1,0-12,0 với bước nhảy $1 \mathrm{pH}$. Kết quả, hoạt tính ở $\mathrm{pH}=4$ là cao nhất. Đối với pectinase có nguồn gốc từ nấm mốc $\mathrm{pH}$ 3,0-5,0 
là pH hoạt động tối thích (L. D. Nguyen, Cao, \& Nguyen, 2004). Kết quả nghiên cứu trên cũng tương đồng với Dogan và Tari (2008), Kant và cộng sự (2013).

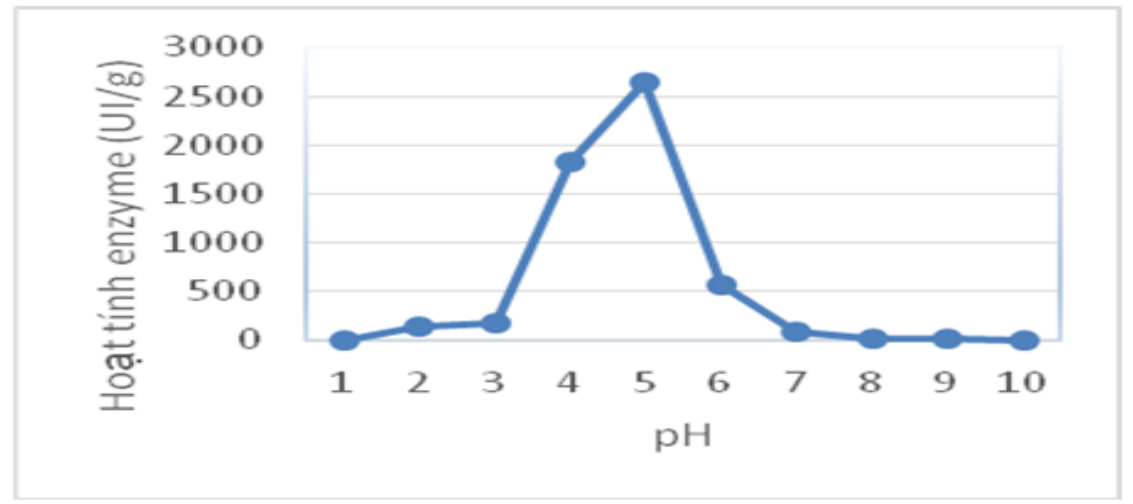

Hình 2. Ảnh hưởng của $\mathrm{pH}$

\subsection{Khảo sát ảnh hưởng của nhiệt độ}

Hoạt tính enzyme tăng nhẹ từ 10 đến $30^{\circ} \mathrm{C}$, tăng nhanh từ 30 đến $40^{\circ} \mathrm{C}$, từ $40 \div 50^{\circ} \mathrm{C}$ hoạt tính enzyme giảm nhẹ, từ $50 \div 80^{\circ} \mathrm{C}$, hoạt tính enzyme giảm mạnh và từ $80 \div 90^{\circ} \mathrm{C}$ thì enzyme gần như mất hoạt tính. Vậy hoạt tính enzyme tối ưu ở $40^{\circ} \mathrm{C}(2658,9 \mathrm{UI} / \mathrm{g})$.

Nhóm tác giả Anand và cộng sự (2017) đã khảo sát hoạt tính enzyme pectinase từ Aspergillus niger trong khoảng nhiệt độ từ $10-100^{\circ} \mathrm{C}$. Kết quả, hoạt tính enzyme ở $50^{\circ} \mathrm{C}$ là cao nhất. Theo Dogan và Tari (2008), Thakur, Pahwa, Singh, và Gupta (2010) thì nhiệt độ tối ưu cho một số chủng nấm sinh enzyme pectinase là $40 \div 60^{\circ} \mathrm{C}$. Đa số enzyme bị mất hoạt tính ở nhiệt độ trên $70^{\circ} \mathrm{C}$. Phần lớn enzyme hoạt động mạnh nhất ở nhiệt độ $40-50^{\circ} \mathrm{C}$. Enzyme pectinesterase từ nấm mốc có nhiệt độ tối ưu là $30-45^{\circ} \mathrm{C}$ và bị vô hoạt ở $55-62^{\circ} \mathrm{C}$. (L. D. Nguyen et al., 2004).

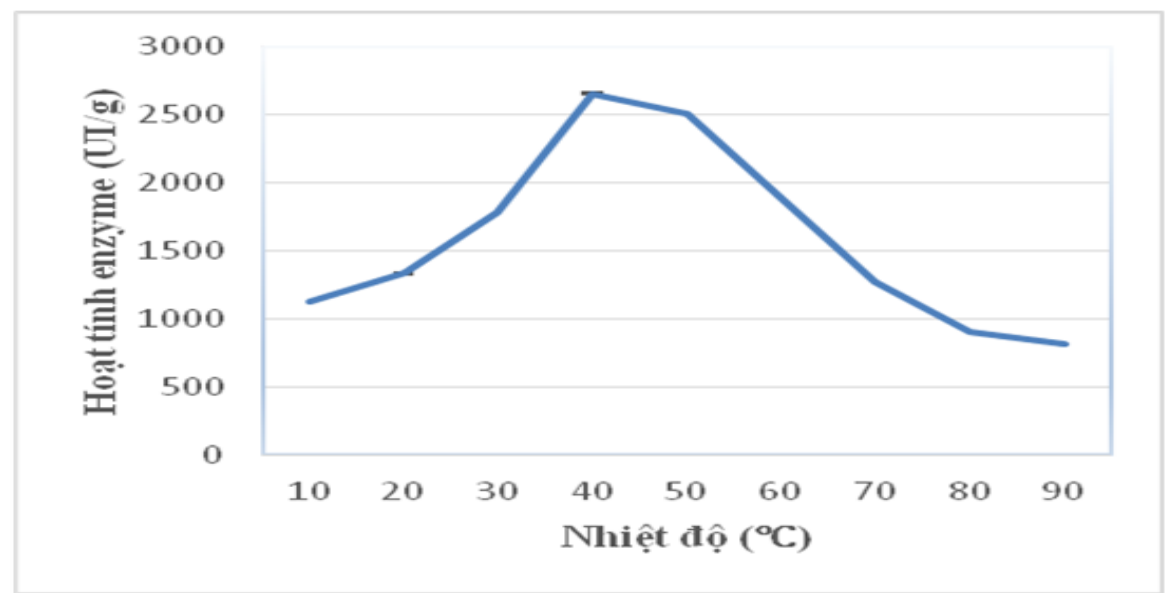

Hình 3. Ảnh hưởng của nhiệt độ 


\subsection{Xác định ảnh hưởng của chất ức chế và chất hoạt hóa}

Chất hoạt hóa là chất làm tăng hoạt tính của enzyme, ngược lại chất ức chế sẽ làm giảm hoạt tính enzyme.

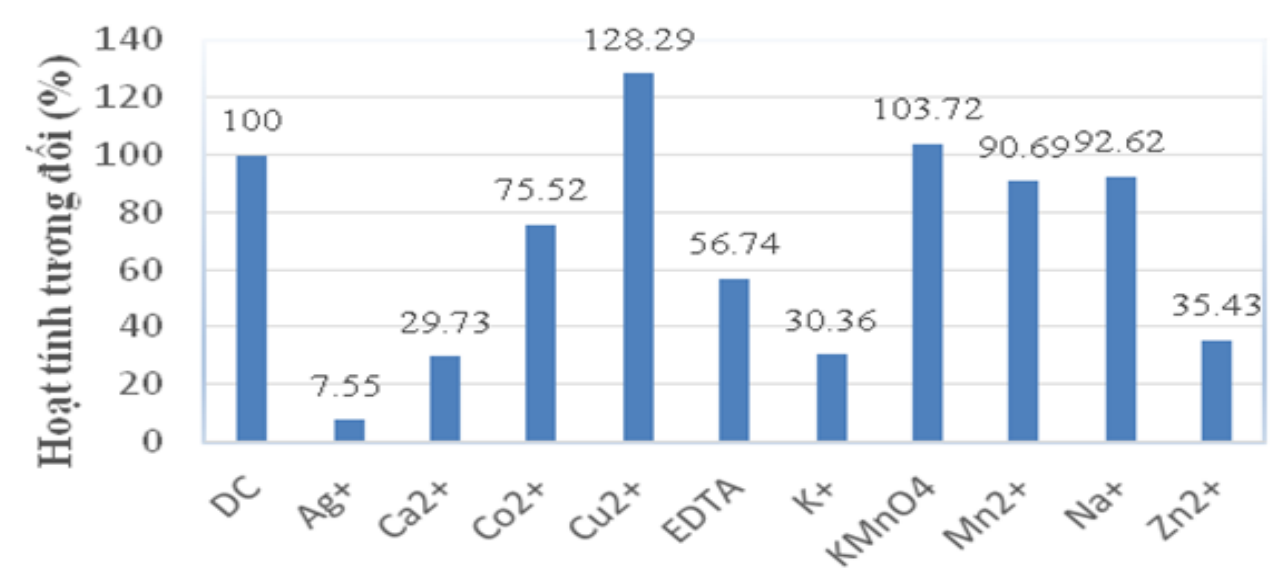

Chất hoạt hóa và chất úxc chế

Hình 4. Ảnh hưởng của chất hoạt hóa và chất ức chế

Mức độ ảnh hưởng của các ion kim loại và chất ức chế protein đối với enzyme pectinase là khác nhau. Đối với các ion $\mathrm{Mn}^{2+}, \mathrm{Na}^{+}, \mathrm{KMnO} 4$ gần như không làm thay đổi hoạt tính enzyme. EDTA làm giảm gần $50 \%$ hoạt tính enzyme. $\mathrm{Ca}^{2+}, \mathrm{Zn}^{2+}$ và $\mathrm{K}^{+}$làm hoạt tính enzyme giảm khoảng $2 / 3$ so với đối chứng. Ion $\mathrm{Co}^{2+}$ làm hoạt tính enzyme giảm khoảng $25 \%$. Ion $\mathrm{Ag}^{+}$thì gần như làm mất hoạt tính enzyme, ion $\mathrm{Cu}^{2+}$ thì làm tăng hoạt tính enzyme. Như vậy ion $\mathrm{Ag}^{+}$ có thể coi là chất ức chế đối với enzyme pectinase, ion $\mathrm{Cu}^{2+}$ thì được coi là chất hoạt hóa. Kết quả này cũng tương đồng với nghiên cứu của Anand và cộng sự (2017). Ion $\mathrm{Cu}^{2+}$ được coi là chất hoạt hóa đối với enzyme endo polygalacturonase từ nấm mốc Aspergillus fumigatus (Anand, Yadav, \& Yadav, 2016).

\section{Kết luận và kiến nghị}

\subsection{Kết luận}

Nghiên cứu đã xác định được nồng độ chất trợ sấy $10 \%$ matodextrin, nhiệt độ sấy $130^{\circ} \mathrm{C}$, tốc độ nhập liệu $288 \mathrm{~mL} / \mathrm{h}$ để tạo chế phẩm enzyme pectinase dạng bột bằng phương pháp sấy phun. Ngoài ra, nghiên cứu đã xác định một số đặc tính của chế phẩm enzyme thu được: thông số động học $\mathrm{Km} 28,4 \mathrm{mg} / \mathrm{mL}$, nhiệt độ $40^{\circ} \mathrm{C}$, và $\mathrm{pH} 5,0$ tối ưu, chất hoạt hóa $C u^{2+}$, chất ức chế $\mathrm{Ag}^{+}$ảnh hưởng đến hoạt động của chế phẩm enzyme.

\subsection{Kiến nghị}

Khảo sát thêm độ bền nhiệt và tính ổn định các $\mathrm{pH}$ khác nhau của chế phẩm enzyme để có hướng sử dụng phù hợp. Đồng thời khảo sát thêm ảnh hưởng của điều kiện bảo quản đến hoạt tính enzyme. Bên cạnh đó ứng dụng thử nghiệm pectinase dạng bột vào việc sản xuất mứt quả.

\section{LỜI CẢM ƠN}

Trân trọng cảm ơn sinh viên Nguyễn Hoàng Minh Nhật, Trần Đông Anh, Võ Hữu Thái An đã hỗ trợ trong quá trình thực hiện nghiên cứu này. 


\section{Tài liệu tham khảo}

Ahlawat, S., Mandhan, R. P., Dhiman, S. S., Kumar, R., \& Sharma, J. (2008). Potential application of alkaline pectinase from Bacillus subtilis ss in pulp and paper. Industry Applied Biochemistry and Biotechnology, 149(3), 287-293.

Anand, G., Yadav, S., \& Yadav, D. (2016). Purification and characterization of polygalacturonase from Aspergillus fumigatus MTCC 2584 and elucidating its application in retting of Crotolaria juncea fiber. 3 Biotech, 6, Article 201.

Anand, G., Yadav, S., \& Yadav, D. (2017). Production, purification and biochemical characterization of an exo-polygalacturonase from Aspergillus niger MTCC 478 suitable for clarification of orange juice. 3 Biotech, 7, 1-8.

Barman, S., Sit, N., Badwaik, L. S., \& Deka, S. C. (2015). Pectinase production by Aspergillus niger using banana (Musa balbisiana) peel as substrate and its effect on clarification of banana juice. Journal of Food Science and Technology, 52(6), 3579-3589.

Cabral, A. C. S., Said, S., \& Oliveira, W. P. (2009). Retention of the enzymatic activity and product properties during spray drying of pineapple stem extract in presence of maltodextrin. International Journal of Food Properties, 12(3), 536-548.

Chen, Y., Sun, D., Zhou, Y., Liu, L., Han, W., Zeng, B., ... Zang, Z. (2014). Cloning, expression and characterization of a novel thermophilic polygalacturonase from Caldicellulosiruptor bescii DSM 6725. International Journal of Molecular Sciences, 15(4), 5717-5729.

Dao, L. T. M., Nguyen, M. T. Q., Do, T. H. T., \& Nguyen, P. T. N. (2017). Khảo sát quá trình tạo chế phẩm bromelain dạng bột từ phụ phẩm dứa [Investigate the process of making powdered bromelain from pineapple by-products]. Tạp chi Khoa hoc Công nghệ và Thưc phẩm, 12(1), 19-32.

Desai, K. G. H., \& Park, H. J. (2005). Recent developments in microencapsulation of food ingredients. Drying Technology, 23(7), 1366-1367.

Devakate, R. V., Patil, V. V., Waje, S. S., \& Thorat, B. N. (2009). Purification and drying of bromelain. Separation and Purification Technology, 64(3), 259-264.

Dogan, N., \& Tari, C. (2008). Characterization of three phase partitioned exopolygalacturonase from Aspergillus sojae with unique properties. Biochemical Engineering Journal, 39(1), 43-50.

Heller, M. C., Carpenter, J. F., \& Randolph, T. W. (1999). Protein formulation and lyophilization cycle design: Prevention of damage due to freeze-concentration induced phase separation. Biotechnology and Bioengineering, 63(2), 166-174.

Huynh, T. P. P., \& Do, H. T. (2018). Khảo sát các yếu tố ảnh hưởng đến khả năng sinh tổng hợp enzyme pectinase từ Aspergillus niger trên nguồn cơ chất vỏ cam [Investigation of factors affecting the ability of pectinase enzyme biosynthesis from Aspergillus niger on orange peel substrate source]. Tạp chi Khoa học Công nghệ và Thục phẩm, 16, 54-60. 
Kant, S., Vohra, A., \& Gupta, R. (2013). Purification and physicochemical properties of polygalacturonase from Aspergillus niger MTCC 3323. Protein Expression and Purification, 87(1), 11-16.

Martins, E. S., Leite, R. S. R., Silva, R., \& Gomes, E. (2013). Purification and properties of polygalacturonase produced by thermophilic fungus Thermoascus aurantiacus CBMAI756 on solid-state fermentation. Enzyme Research, 2013(2), 1-7.

Miller, G. L. (1959). Use of dinitrosalicylic acid reagent for determination of reducing sugar. Analytical Chemistry, 31(3), 426-428.

Mohsen, S. M., Bazaraa, W. A., \& Doukani, K. (2009). Purification and characterization of Aspergillus niger U-86 polygalacturonase and its use in clarification of pomegranate and grape juices. The 4th Conference on Recent Technology in Agriculture, 84, 805-816.

Nakkeeran E., Umesh-Kumar, S., \& Subramanian, R. (2011). Aspergillus carbonarius polygalacturonases purified by integrated membrane process and affinity precipitation for apple juice production. Bioresource Technology, 102(3), 3293-3297.

Nguyen, L. D., Cao, C., \& Nguyen, T. A. (2004). Thu nhận enzyme tù vi sinh vật. Công nghệ enzyme, tù̀ lần 2, [Obtain enzymes from microorganisms. Enzyme technology, since the 2nd,] (pp. 356-376). Ho Chi Minh, Vietnam: NXB Đại học Quốc gia Thành phố Hồ Chí Minh.

Nguyen, N. T. T., \& Nguyen, M. T. H. (2011). Tối ưu hóa quá trình sấy phun dịch cà chua [Optimization of tomato juice spray drying]. Tạp chí Khoa hoc và Phát triển, 9(6), 10141020.

Nguyen, P. N. M., Che, H. V., Ly, B. N., \& Chau, A. T. D. (2011). Tác động enzyme pectinase đến khả năng trích ly dịch quả và các điều kiện lên men đến chất lượng lượng rượu vang xoài sau thời gian lên men chính [Effects of pectinase enzyme on juice extraction and fermentation conditions on mango wine quality after main fermentation time]. Tap chí Khoa học Truờng Đại học Cần Tho, 20(a), 127-136.

Nguyen, T. V., Nguyen, T. M., Le, N. H., \& Le, H. T. (2013). Trích ly enzyme Bromelain từ phế phẩm khóm Cầu Đúc-Hậu Giang [Extraction of Bromelain enzyme from Cau DucHau Giang pineapple waste product]. Tạp chi Khoa hoc Truòng Đại hoc Cần Tho, 28, 21-27.

Pan, X., Li, K., Ma, R., Shi, P., Huang, H., Yang, P., ... Yao, B. (2015). Biochemical characterization of three distinct polygalacturonases from Neosartorya fischeri P1. Food Chemistry, 188, 569-575.

Parenicova, L., Benen, J. A., Kester, H. C., \& Visser, J. (1998). PgaE encodes a fourth member of the endopolygalacturonase gene family from Aspergillus niger. European Journal of Biochemistry, 251(1/2), 72-80.

Samborska, K., Witrowa-Rajchert, D., \& Gonçalves, A. (2005). Spray-drying of $\alpha$-amylase the effect of process variables on the enzyme inactivation. Drying Technology: An International Journal, 23(4), 941-953. 
Thakur, A., Pahwa, R., Singh, S., \& Gupta, R. (2010). Production, purification, and characterization of polygalacturonase from Mucor circinelloides ITCC 6025. Enzyme Research, 2010, Article 170549.

Tran, X. T., Duong, T. V., \& Le, L. T. H. (2012). Nghiên cứu sủ dụng hệ enzyme pectinase, cellulase của vi khuẩn B.subtilis, L.plantarum và nấm mốc A.niger, Ph.chrysosporium để xủ lý lớp nhớt của vỏ cà phê. Paper presented at Tuyển tập báo cáo hội nghị sinh viên nghiên cứu khoa học lần thứ 8 , Đại học Đà Nẵng, Danang, Vietnam.

Walker, J. M. (1996). The protein protocols handbook 2. New York, NY: Springer Science \& Business Media. 